\title{
How a Shattered Civil Religion is Rebuilt Through CONTESTATION: URUGUAY AND THE LEGACY of AUTHORITARIANISM
}

\author{
Reconstruir una religión civil a través de la confrontación: \\ Uruguay y el legado del autoritarismo
}

\section{LUIS RONIGER}

Wake Forest University

\begin{abstract}
This articles analyzes how Uruguay, a country that historically grounded its collective identity on civil premises, attempted to reconstruct it after that vision was shattered by the mounting political violence of the 1960s-70s and the civilian-military dictatorship that ruled the country from 1973 to 1985 . At the basis of this process, the article identifies the ongoing debates and demands by sectors of society to come to grips with the legacy of authoritarianism in a way that restored legal accountability, truth and justice as basic to core national principles. It claims that this process prompted a critical vision of earlier understandings, which has enabled the coexistence of opposing worldviews without eroding democracy, unlike in the past. The Uruguayan case is of particular comparative relevance for societies where contestation often spills over into political polarization, civil wars and human rights violations.
\end{abstract}

Key words: Civil religion, authoritarianism, human rights violations, legal immunity, judicial accountability, contestation.

\section{RESUMEN}

Este artículo analiza la forma en que Uruguay, un país que basó su identidad colectiva en una religión civil, logró reconstruirla con el retorno de la democracia. La visión civilista uruguaya había sido destruida bajo el impacto de la creciente violencia politica en las décadas de 1960-70 y la dictadura de 1973-1985 que dejó un legado masivo de violaciones de derechos humanos. El trabajo destaca cómo en la última generación Uruguay logra reconstruir su identidad colectiva mediante un proceso de confrontación que cuestiona el pasado mientras permite la coexistencia de perspectivas opuestas que, a diferencia del pasado, no erosionan la democracia. Comparativamente, el estudio del caso uruguayo es sumamente relevante para sociedades donde confrontaciones desembocan en polarización política, guerras civiles y legados de violaciones a los derechos humanos.

Palabras clave: Religión civil, autoritarismo, violaciones de derechos humanos, inmunidad legal, rendición de cuentas ante la justicia, confrontación política. 


\section{INTRODUCTION}

Civil religions are easier to sustain than rebuilt once shattered. This contribution analyzes how Uruguay, a country that historically grounded its collective identity on civil premises attempted to reconstruct it after that vision was shattered due to the mounting political violence of the 1960s-70s and the civilian-military dictatorship that ruled the country from 1973 to 1985. It discusses how in the last generation Uruguay engaged -through a process of contestation of elites and society- to rebuild its civil religion, albeit in more critical terms, thus enabling the existence of opposing worldviews without eroding its democracy, unlike in the past, and moving the agenda to other issues, among them perceived public insecurity.

The comparative relevance of this analysis lies in identifying the balance that Uruguayans achieved between the need for reaching consensual agreements and the wish of many to get involved and challenge the policies drafted by political elites after a period of dictatorship and human rights violations. At the basis of this process, the article identifies the ongoing debates and demands by sectors of society to come to grips with the legacy of authoritarianism in a way that restored legal accountability, truth and justice as basic to core national principles.

\section{ANALYTICAL BACKGROUND: CIVIL RELIGION AND URUGUAY'S HISTORICAL EXPERIENCE}

Civil religion can be defined as an implicit set of core values at the basis of life in society. Conceived as cemented by public rituals, symbols and ceremonies, the concept has multiple roots traced back to the idea of a post-Hobbesian social contract, and became widely used following the work of Robert Bellah $(1967,1982)$ on the sociology of religion. The concept can be interpreted as addressing a substantive social concern with social cohesiveness and dissent and referring to their institutionalization or de-institutionalization. Such core values are structured by political mechanisms, legal frameworks and social practices. Imbricated implicitly as the "moral fabric of society" and in a tense-ridden relationship with other trends of modernity, civil religion is nonetheless deemed as providing an important basis, not the only one, for linking specific institutional arrangements within broader commitments and understandings (Eisenstadt and Roniger, 1984: 1-42; Eisenstadt, 1995). In this sense, civil religion is one dimension, important yet far from unique, ${ }^{1}$ in the development of civil society and public spheres at large, concepts also relevant to the analysis of Uruguay. Indeed, scholars working on Uruguay have stressed the centrality of this conceptual construction while situating it historically (Caetano and Geymonat, 1997; Caetano, 2011; Da Costa, 2011), or problematizing it in terms of its homogenizing myth-making while questioning its claims of egalitarian praxis (Guigou, 2003, 2010).

1 In many historical and contemporary contexts, it is organized on radical religious parameters that shape public spheres and define the core values of society. 
Projected through modern times, the idea of civil society entered political thought through the works of Locke, Ferguson and Smith, Rousseau and finally Hegel and Tocqueville, who expressed in various ways the emergence of an inclusive set of institutions and networks outside the purview of the state and institutional churches (Seligman, 1993; Joas and Wiedgandt, 2008). Paradigmatic of this conception was the network of public and private associations and organizations, both religious and secular, which promoted cooperation and created the basic structure of trust and moral texture to society. As Jeffrey Alexander (1998) once noted, this conception was challenged in the Western world as the democratic associative ties were side-lined by industrial capitalism, markets and the state. With civility and cooperation distorted by "ravenous capitalism", it took the onslaught of authoritarian statehood in the twentieth century for civil society and its network of non-market and non-individualistic forces to be reckoned again as a powerful source of autonomous collective life.

Closely connected to the above and somehow more neutral in recognizing contradictory trends in the midst of society, is the concept of public spheres, referring to realms that -while public-develop autonomously from states. Historically, public spheres developed as the arena in which private sectors come together for the purpose of interacting discursively and of engaging with the state "in a debate over the general rules governing relations in the basically privatized but publicly relevant sphere of commodity exchange and social labor" (Habermas, 1989: 27). In Nancy Fraser's classic definition, it "is the space in which citizens deliberate about their common affairs, and hence an institutionalized arena of discursive interaction. This arena is conceptually distinct from the state; it is a site for the production and circulation of discourses [and, we may add, actions] that can in principle be critical of the state" (1992: 110). The concept wields heuristic force worldwide for analyzing varied situations of growing or decreasing autonomy in society vis-à-vis the state and within the formal structures of the state. It thus alludes to a multiplicity of interpenetrated arenas and spheres of interaction, some of which are rather "uncivil" if judged by criteria of equality, justice and legality, but they are still important for recognizing plurality and diversity beyond the realm of markets and states, such as clientelism (Hilgers, 2012) or the jati system of India (Sen, 2005: 34-44). As such, it can be applied cross-culturally, both in Western societies that saw its crystallization and beyond them (Wakeman, 2009). It is in the public spheres where contestation and participation, the two main processes that ensure the workings of democracy, may take place. In turn, it is the domain that authoritarian rulers and totalitarian regimes aim to constrict and strictly control through the state machinery and repression, propaganda and indoctrination. For Uruguay, Gerardo Caetano's La República Batllista has reconstructed in detail how late $19^{\text {th }}$ and early $20^{\text {th }}$ century political actors and intellectuals managed -through their intense debates and tacit negotiations- to construct a liberal republicanism enshrining core civic values of citizenship (Caetano, 2011).

With these analytical distinctions in mind, we can review shortly their unfolding in the Uruguayan case. Until the early $20^{\text {th }}$ century, the history of Uruguay resembled that of other South American countries, clustered around a long series of internal conflicts and transnational wars. Yet, unlike neighboring Argentina, by the early twentieth century 
Uruguay succeeded in reaching wide agreement among political forces and elaborated a national vision centered upon the recognition of republican citizenship and its entitlements. From that optic, the so-called Oriental (i.e. Uruguayan) nation was defined by republican virtues and the principle of political order and rights guaranteed by the state (Caetano, 2011), without grounding on primordial roots (Halperín Donghi, 2014: 158-173; Roniger, 2008). By the late $19^{\text {th }}$ century and the $20^{\text {th }}$ century these images were projected by the state in seemingly universal terms, even though the initial criteria of citizenship were rather restrictive. Thus, representation was limited according to several conditions: personal status (slaves and dependent workers were not granted electoral rights), gender (females were excluded), age (minors until the age of 21 did not enjoy franchise), and education (illiterates were precluded from the electoral process after 1840). In addition, even if formally abolished, indebted work continued into the second half of the $19^{\text {th }}$ century (Verdesio, 2001). Moreover, Uruguayan citizenship entailed a cultural program that disregarded and neglected indigenous, Afro-descendent or immigrant identities, expecting them to vanish within the homogenizing ethos of the nation-state (Guigou, 2010).

Particularly bold was the separation of state and [Catholic] Church. As described by Néstor da Costa, the process unfolded towards a comprehensive secularization of institutional arenas, thus creating a system of laïcité that followed closely -but did not replicate- the French historical experience:

In 1861 a "secularization of cemeteries" occurs, that is, the cemeteries were no longer run by the Catholic Church, but moved to the state. In 1863 the Bishop of Montevideo was banished due to conflicts with the government. Between 1865 and 1878 the so called "intellectual conflict" developed, which consisted of strong clashes in the media as well as the protagonist emergence of Liberal and Catholic intellectual centers. In 1877 the Education Act was enacted, taking out religion from the educational system. In 1879 the Civil Registration Act was enacted, which passes from the hands of the Catholic Church to the state. In 1885 the Convents Act was enacted, which annulled the legal status of all convents (...) In 1906 crucifixes were removed from all public hospitals, and in 1907 the Divorce Act was enacted. Also in 1907 all references to God and the gospels were deleted from the oath that members of Parliament take. In 1917 a constitutional reform establishes the legal and real separation of church and state, with a formula set out in article 5 of the [1918] Constitution (...) In 1919 what historians have called a secularization of the holidays took place [as reflected in the change of name of the holidays]. Finally, also a change of names of settlements, which involved the renaming of towns with (...) secular names (Da Costa, 2009: 8, 10. See also Caetano and Geymonat, 1997).

Nonetheless, while modelled after the French experience, Uruguay developed a pluralist understanding of laïcité. Unlike the radical French model, Article 5 of the Constitution enshrined a separation of state and church with pluralist connotations, predicated upon the freedom of consciousness and freedom of religion, albeit displaced from most public arenas: 
Art. 5. Todos los cultos religiosos son libres en el Uruguay. El Estado no sostiene religión alguna. Reconoce a la Iglesia Católica el dominio de todos los templos que hayan sido, total o parcialmente, construidos con fondos del Erario Nacional, exceptuándose solo las capillas destinadas al servicio de asilos, hospitales, cárceles u otros establecimientos públicos. Declara, asimismo, exentos de toda clase de impuestos a los templos consagrados actualmente al culto de las diversas religiones. ${ }^{2}$

Furthermore, as emphasized by Blancarte (2006) and Da Costa (2011), the Uruguayan understanding of laïcité implied also a mode of collective life legitimated in terms of popular sovereignty and state neutrality. With the passing of time, the vision of Uruguayan nationhood became embodied in the civil religion of citizenship and state accountability and impartiality, almost without primordial or confessional underpinnings, albeit no less sacralized. The National (Blanco) Party leader Wilson Ferreira Aldunate expressed this view when emphasizing the role of the state and its principles on the definition of the nation, as he addressed the Chamber of Deputies of Ecuador in 1983, speaking from exile during the dictatorship in Uruguay:

This is why we are a most authentic country, (...) not due to the influence of a common race, in a genetic sense; neither as a result of geography, but rather by being a spiritual community. It consists in the cult of certain things: equality before the law, the representative character of the organs of government, the periodic election of the rulers, the subordination of any authority and power center to the civilian government, the strict obedience to the guarantees of freedom, of political freedom and individual freedom. ...Among us, when there is an attack against the survival of these spiritual values the very existence of the country is put under risk, since the country is that and if [these elements are] absent, it is not a country (Demasi, 1995: 47-48).

Even though there are still debates open on the role played by individuals and institutions in the constitution of the Oriental nation, and ongoing controversies on the display of religious symbols in public space, the view described by Ferreira Aldunate became widely accepted by the 20th century. That vision became "routinized" as part of the process of socialization and universal education carried out by the Uruguayan state and its leading political and cultural elites. In the words of Fernando Andacht (1992: 25; Da Costa, 2009),

Removing the official religion, reducing it to a family, internal dissent, with little public visibility, did not eliminate religion, but only the established religion. (...) Without knowing it consciously, another form of religion was founded, as powerful as that which was fought relentlessly. The Catholic faith was effectively displaced from the social imaginary, but the state and its boundless natural gifts took the place of the divine mystery. 'Mesocracy' [roughly, the faith in a society of equals] was the ideology that arose when the community received the religion of the social realm 
instead of an established religion. This way of organizing the [social] mood became Uruguayan's main twentieth-century religion.

Uruguayans came to endorse the narrative of a civil religion grounded in public values. They saw it reflected in -and sustained by- universal education, development, welfare benefits and open public spheres. Grounded on such shared vision as promoted in the first half of the twentieth century, Uruguay was praised as being the "Switzerland of the Americas", a content nation often referred as the "happy Uruguay". The country imagined itself as a civilized nation, closer to European than to other Latin American countries not just in demographic composition, but also and primarily in institutional performance and collective vision. There were already at that stage indications of a disjuncture between the image and real life, as evident in the inflationary character of the welfare state structures (Benedetti, 1966) and the use of violence as way of settling conflicts in society (Kierszenbaum, 2012: 35-48; Guigou, 2010: 163-181), yet these were mostly glossed over by society at large.

These images were shattered by social and political conflicts in the third quarter of the $20^{\text {th }}$ century. The inability to sustain the development model, compounded by mounting unsatisfied demands, "revolutionary" violence and counter-violence in the 1960s and early 1970s undermined the viability of Uruguayan democracy. The deepening conflict led to the growing involvement of the armed forces in government, the closure of the parliament, and by June 1973, the establishment of a civilian-military dictatorship. The civilian-military government imposed authoritarian controls and carried out widespread repression, long term imprisonment and torture of thousands of citizens suspected of left-wing sympathies (Uruguay nunca más, 1989: 111-15, 425-30; Roniger and Sznajder, 1999: 7-50).

The experience of the dictatorship profoundly affected the collective perceptions of Uruguayan society, which until the early 1970s prided itself to be a model democracy and exemplary welfare state. It questioned that vision, forcing a collective inquiry, marked by the subsequent need to develop policies that could address the legacy of authoritarianism. The dictatorship affected not only the democratic institutions, but also shook the vision of Uruguay as a civilized nation able to work out consensual agreements. Consequently, reshaping the civil religion of the nation after the restoration of democracy became for Uruguay an imposing challenge faced on a decades-long span.

\section{THE URUGUAYAN TRANSITION AND ITS CHALLENGES}

The policies of the civilian-military dictatorship had long lasting effects on the perception of both supporters and victims, as well as on broad sectors not directly affected by physical repression. Following the return to democracy in 1985, Uruguayans came to realize the extent and magnitude of the problem of balancing policies of democratic stability with the demands of truth and justice for the victims of repression. Intense debates and uneven progress around the institutional and informal mechanisms needed to face the dark legacy of authoritarianism developed already during the so called period 
of "transitional dictatorship" of General Gregorio Álvarez (1981-85) and became more intense once the authoritarian controls were lifted (Caetano, 1987).

Restoring democracy in Uruguay involved not just reinstating free speech and renewing the work of the institutions of polyarchy. It also forced a confrontation with the past and a collective search for policies that could address the legacy of authoritarianism. The challenge was complex. On the one hand, the road to transitional justice had been blocked by the negotiated character of the process of democratic restoration. Re-democratization resulted from an agreement between the military and the main political parties. On 30 November 1980, the rulers had attempted to get popular approval for a project of constitutional reform that would enshrine their authoritarian blueprint for Uruguayan society. The constitutional project envisioned a model that demobilized civil society, restricted its autonomy and limited political participation. Unlike Chile, the project failed to pass and yet the military retained a large measure of control over the political process. This allowed them to move towards democracy in a process negotiated with civilian political elites, but strongly biased by their will to dictate the terms of the transition.

During the long period of political proscription, NGOs dealing with human rights, and especially the Servicio de Paz y Justicia (SERPAJ), led by Jesuit Fr. Luis Pérez Aguirre, had found a voice that increasingly resonated in society and among the political class. In the early stages of political opening, those NGO leaders coordinated contacts between various political sectors, creating a synergy inexistent until then. Fr. Pérez Aguirre denounced the hypocritical attitude of the military, which continued to torture prisoners while negotiating with politicians. The military stopped negotiations in reprisal, and a two weeks' hunger strike by Fr. Pérez Aguirre and other SERPAJ activists, supported by politicians, brought about their reconvening. Another critical event was the death of Communist physician Vladimir Roslik, as a result of detention and torture, on April 1984. This case was covered in detail by the media, which, along with the main political forces and the international community, demanded explanations. The military responded by closing some media and harassing journalists that reported the case. Yet, as a result of the Roslik case, the Colorado Party adopted the banner of human rights, and a wide public consensus emerged against human rights violations. The Colorados' role was strengthened relative to other forces in the opposition, and the Communist Party was included as a legitimate political actor.

Having also a major impact on public opinion was the unexpected visit of 154 children of Uruguayans living with their parents in exile in Europe. Taking place in December 1983, it was organized at the initiative of a Comisión por el Reencuentro de los Uruguayos, supported by the Comite internacional pro-retorno del exilio uruguayo, the Asociación española de ayuda al refugiado (CEAR) the Spanish Red Cross and the PSOE party. Accompanied by Spanish deputies and senators and representatives of the sponsoring organizations and the public, the Uruguayan government could not stop the children's visit to their relatives for Christmas. About 500 relatives and thousands of others welcomed the children at the Carrasco Airport and a convoy of 20 buses took them to downtown Montevideo, with the crowd chanting slogans against the dictatorship that included the 
promise to bring their parents back to Uruguay (Camacho, 1983). The move raised the consciousness of the problem of exile. It contributed after democratization to the design of policies facilitating the return and reincorporation of those who had been forced to flee abroad in order to preserve their freedom and physical integrity during the dictatorship.

In August 1984 military commands and leading politicians reached an agreement intended to enable elections and the transition to civilian rule. The main negotiators, general Hugo Medina and Colorado Party leader Julio María Sanguinetti, had to balance contradictory pressures. The hardliners in the army demanded explicit legal immunity, yet such a move would have pushed the leftist political forces out of the negotiations. Public statements by general Medina indicated that only military personnel who had committed "disqualifying actions" (e.g. theft and rape) would be brought to trial. The agreement, later known as the Naval Club Pact, remained secret and was denounced by Ferreira Aldunate, who had narrowly escaped death in 1976 while in exile in Argentina and became a leading voice censuring the regime and those willing to compromise with its legacy. Yet, the negotiated political opening implied that the perpetrators of human rights violations would go unpunished.

Another challenge stemmed from the disjuncture between the older visions and the new expectations from democracy. Both the armed forces and the former Tupamaros as well as major parts of the main political parties projected onto democracy a shared view that what happened under the dictatorship was the result of a war in which both camps "played their role". ${ }^{3}$ A change of minds had to be operated in order for major sectors of society to approach past state repression and violence in terms of human rights violations. Only progressively the outcry of the victims and those endorsing the claim for justice and an end to impunity would prompt a tense-ridden and protracted confrontation with authoritarianism.

Following democratization, Uruguay also faced the problem of weighing the adoption of policies of truth and justice for the victims of repression, while reconstructing institutions. Major sectors of the political class and society wanted to move ahead by closing the book on the past instead of opening "old wounds", which could polarize society again and threaten the restored democracy. This situation was typical of transitions to democracy conducted by military high commands from a position of relative strength. In the case under consideration, confronting that challenge would converge with the will to restore some of the pristine values of Uruguayan civil religion.

\section{MECHANISMS OF CLOSURE}

The Uruguayan way of engaging these challenges and dilemmas was to pass two laws. The first was an amnesty law for most political prisoners (Ley de pacificación nacional),

Significantly, for years most members of the urban guerrilla of the Tupamaros retained the view that torture and long term imprisonment were the price individuals paid for their revolutionary struggle. At first they rejected a discourse of victimhood supported by the human rights organisations, and shifted towards it only belatedly and pragmatically. See Markarian (2005) and Achúgar (2006). 
passed in March 1985, allowing their release, with the exception of those serving sentences for murder; restoring their property; and compensating them for financial losses. The second was a Law of Expiry (Ley de caducidad de la pretensión punitiva del Estado or Law of Expiry on Punitive Claims by the State), passed in December 1986. The law provided immunity to those who performed acts constituting violations of human rights prior to March $1^{\text {st }} 1985$, when democracy was restored, save in 'exceptional' cases involving illicit enrichment, rape, disappearance of citizens or abduction and illegal adoption of children. In those specific cases, Article I-4 recognized the President's right to order the opening of a judicial investigation:

Artículo $4^{\circ}$.- Sin perjuicio de lo dispuesto en los artículos precedentes el Juez de la causa remitirá al Poder Ejecutivo testimonios de las denuncias presentadas hasta la fecha de promulgación de la presente ley referentes a actuaciones relativas a personas presuntamente detenidas en operaciones militares o policiales y desaparecidas así como de menores presuntamente secuestrados en similares condiciones. El Poder Ejecutivo dispondrá de inmediato las investigaciones destinadas al esclarecimiento de estos hechos. El Poder Ejecutivo dentro del plazo de ciento veinte días a contar de la comunicación judicial de la denuncia dará cuenta a los denunciantes del resultado de estas investigaciones y pondrá en su conocimiento la información recabada (Ley 15.848. Funcionarios militares y policiales). 4

In addition, the Senate received control over the promotions of military officers; the Ministry of Defense was put in charge of the intelligence services; and Parliament received supervision over the military academy. Additional measures taken by the transition government included the establishment of a National Commission of Repatriation, which operated until 1989, charged with assisting exiles wishing to return home, and a law for the reinstatement of state officials demoted during the dictatorship.

Symmetry was thus supposedly established between repressors and victims, conceived to lead to closure. Nonetheless, the terms of the Naval Club Pact that allowed the transition did not generate a consensual interpretation of past experiences. For years, the military opposed any opening of a judicial-investigative track, threatening to destabilize democracy. Neither did it acknowledge institutional responsibility for the human rights violations committed under its command. Only years after the transition to democracy some members of the armed and security forces began to acknowledge the facts of the past, but mostly in terms of arguing the traditional thesis of the military, according to which they acted in a framework of internal war that prevailed at the time they took power (Achúgar, 2006).

The internal tensions, the inability to carry out trials and especially the lack of knowledge about the whereabouts of the victims and the lack of recognition of military responsibility implied that the legacy of human rights violations continued to reverberate for years. The partiality of the adopted policies projected these issues time and again at the center of the public agenda, prompted by multiple triggers, starting with initiatives of civil 
society yet also due to governmental responses to local disclosures or international pressures (Barahona de Brito, 1997; Roniger and Sznajder, 1999). Accordingly, sectors of civil society challenged the Law of Expiry twice, in a referendum on 16 April 1989 and in a plebiscite called by the state on 25 October 2009. Both initiatives failed to derogate the law and undo the blanket immunity that the negotiated political transition granted repressors. In 2010 the Frente Amplio, the center-left ruling coalition, moved to end this cycle of legal impunity through a parliamentary bill that would have declared the 1986 amnesty law unconstitutional. On May 2011 this initiative failed by one vote to pass at the lower chamber, after being approved by the Senate. On October 2011, the Parliament finally approved an interpretive law that sanctioned the legality of autonomous judicial actions against former military repressors and high-ranking civilians that enabled the breakdown of democracy in the 1970s and the ensuing repression. The fact that human rights violations reverberated time and again in the public agenda and still took decades to finally change the format of legal immunity, despite major breakthroughs in other domains, is at the center of this inquiry.

\section{THE ‘POLITICS OF CLOSED DOORS’ AND CIVILIAN CONTESTATION}

Until the restoration of democracy, the Uruguayan political process had been shaped in the traditional way of doing politics during democratic periods. Politicians were used to reach agreement on the core issues deliberating among themselves, while social movements were weak and failed to exercise significant influence over the system of partidocracia or rule by party elites (Caetano et al., 1985; Kaufman, 1987: 25-62; González, 1993).

The Law of Expiry can be seen as another attempt to validate this style of politics and bypass a principled public debate on an issue with explosive implications for a restored democracy. However, a new scenario developed as sectors of civil society challenged the 'politics of closed doors' and mobilized to reach a referendum on the Law. The move was possible since the 1967 Uruguayan constitution, put in force again, contemplated a mechanism of direct democracy; namely, conducting a referendum if 25 percent of the electorate demanded it. Those opposed to the statute of immunity mobilized in massive demonstrations and started the painstaking process of collecting signatures. Protest was started by the MLN-National Liberation Movement of the Tupamaros. Soon the movement was led by a Committee of Mothers and Relatives of Missing Persons (represented by María Esther Gatti de Islas), along with Matilde Rodríguez and Elisa Dellepiane, the widows of Héctor Gutiérrez Ruiz and Zelmar Michelini, two renowned politicians who were assassinated in May 1976 in Buenos Aires by a joint Uruguayan-Argentine task force. NGOs, especially SERPAJ, were also instrumental in coordinating activities. Beginning in January 1987, the campaign was conducted under the umbrella of the National ProReferendum Commission or CNP, headed by those women (Llamamiento, 1987; Burt, 1989). With the memory of authoritarianism still fresh, civil society associations managed to move the issue of state repression and massive human-rights violations -inimical to the projected self-image of the country- to the center of the public agenda.

The driving forces of the referendum claimed to represent the forces of civil society, "inspired by the basic principles of our nation: freedom, democracy, justice and peaceful 
coexistence". The law was considered contrary to the "purest traditions of the Nation", an affront to the democratic sentiments of the Uruguayan people, for whom justice and equality before the law were said to be fundamental. The CNP emphasized that the reaction to the law was part of a process of overcoming the fear of state authoritarianism and a means for the people learning to trust again their own ability to make decisions. Mobilizing allowed people to come together, overcome the reclusion to private life and the shadows of the recent past, and recover an autonomous presence in public spheres. The message was formulated in terms of ethics, justice and truth; of hope, happiness and the value of human life. Through the process of mobilization, food and music events were organized in neighborhoods, and meetings were held, reviving the memory of popular forms of organization and door to door visits (Rodríguez, 1989: 5). Overall, the core tenets of Uruguayan idealized civil religion were reaffirmed in a process of social regeneration and debate expanding from the bottom-up through the work of hundreds of activists.

The terms of the debate are also telling on how the very process of contestation reaffirmed the basic values that had been affected by the dictatorship. The years-long process -spanning from December 1986 to April 1989- saw two camps struggling to gain the hearts and votes of the general population. Facing each other were those willing to repeal the Law of Expiry and those willing to ratify it. An analysis of the terms of debate indicates that both camps addressed, albeit in contrasted ways, several fundamental issues. Even though supporters and opponents of the Law referred to these issues from diametrically opposed perspectives, they around issues that brought them to a shared reflection on how transitional justice would affect their society. Emerging were issues such as how to consolidate democracy, how to avoid a return to dictatorship, how to uphold the principles of justice and equality before the law, and how to define the role of the armed forces in democratic life.

\section{THE PREMATURE SANCTIFICATION OF CONSENSUS}

After reaching the needed signatures, the referendum was conducted on April 16, 1989. The participation rate stood at 84.7 percent, with citizens ratifying the law by a narrow margin of 56.6 percent to 43.3 percent. Despite early polls that revealed that a majority of Uruguayans identified the issues at hand as a moral question, the pragmatic option prevailed when casting the ballots (Portillo y Gallicchio, 1989). Once the results of the referendum were made public, the ruling coalition tried to convince that the subject had been closed forever, sanctifying the idea of a national consensus in the reconstituted democracy. Symbolically, the leading political figures behind the winning option stated that no public celebrations would follow and that there were no "winners or losers" in the referendum.

In military circles, the satisfaction with the results of the referendum was mixed with a narrative of historical justification of their fulfilled mission. Some senior officers like retired general Hugo Posse, Chief of Staff of the armed forces in June 1973, attacked the view that the referendum results with the vote split almost in half signaled the moral 
equivalence of the armed forces and the guerrillas. According to Posse, combating the guerrillas' sedition between 1973 and 1985 had been morally correct, since it maintained order, supported established authorities and saved the country from anarchy. No call for public civility, he said, would obscure the fact that those who use the language of human rights and justice are [still] trying to "disarm the nation in both the material and spiritual sense". (Búsqueda, Montevideo, 20 April 1989, p. 8).

The supporters of derogating the Law also refrained from interpreting the results as an ethical defeat. Their explanation was that the population feared that by annulling the Law they would de-stabilize the renascent democracy; and that they failed to overcome the propaganda of government officials, including the President and Vice-President, who used mass media to a greater extent than the opposition, creating a sense of danger in the event of repelling the Law. They accepted the referendum results, itself applauded as a show of civility and faith in the electoral process, yet at the same time promised "not to forget the martyrs" and to continue fighting for a more "ethical outcome" in the future. They added that the forces of the winning ticket won the day without convincing society, and that the ultimate judgment would be set by the historical record (Mate amargo, publication of the MLN-Tupamaros, 20 April 1989).

The forces in power projected a narrative intended to consecrate consensus. Rhetorical figures of speech were used to reaffirm the unity of Uruguayans and declare the issue closed permanently. Immediately as the polls closed, president Sanguinetti welcomed the referendum as a sign of Uruguayan civility. He stated that in Uruguay issues "are resolved at the ballot box and not by shouting. (...) The vote puts the Republic up to its best traditions" (La República, 17 April 1989, p. 5). In an interview, the President stated that the referendum had concluded the political transition, with controversies left behind and the country facing its future without the weight of the past (El País, Madrid, 19 April 1989, p. 6).

Open debate allowed society to reclaim an autonomous voice in public affairs, in a way that forced a principled discussion of the core challenges of the human rights domain in a post-authoritarian environment. During a period of over two years, culminating in the referendum, the sentiments expressed by many sectors of civil society had concrete implications for the future of democracy, legality and accountability.

In spite of the slight margin, the resolution via referendum was widely accepted as dictated by the popular vote. This served, in subsequent years, as the basis of repeated arguments of political leaders, that the debate had been definitely closed, in supposed contrast to Argentina or Chile, where there were continued ups-anddowns in transitional justice. In Uruguay, many shared the view that the referendum had sealed the issue from a legal and political perspective. The fact that the widely mobilized civil society had the opportunity to challenge the policies of the political class increased the legitimacy of dispute resolution procedures. However, the wide acceptance of the results was linked to a parallel realization that this was an issue that could polarize public opinion and could not be evaded. Speeches reaffirming national reconciliation projected symbolically the desiderata of final closure, soon to 
be reopened through demands for truth, justice, accountability, all values at the center of the professed civil religion of the country.

In the short term, immunity was solidified, allowing former repressors to evade assuming institutional responsibility for human rights violations committed during their stay in power. For years, the Law of Expiry closed the road in hundreds of pending court cases and no repressor was convicted. The defeat after the years-long show of mass mobilization was also detrimental to the ensuing, short-term public interest in the issue. When SERPAJ published its report on the human rights record of the dictatorship a few months later, in September 1989, it elicited little public interest. The report was titled 'Nunca más Uruguay', after the renowned 1984 report of Argentina by the CONADEP, the National Commission of Inquiry on Disappeared Persons. The Uruguayan report was prepared by a team of eight SERPAJ activists, in the absence of any government initiative of an official truth commission. Lacking state support, the report was based on testimonies collected for years by that NGO and a survey of 313 prisoners prosecuted by the military. The informal nature of the work and the modest resources for research and writing prolonged its release for three years. When the report was finally published after the referendum, the edition had only 1,000 copies. Two other editions of 1,000 copies each were published later, yet the report had a limited impact, contrasting significantly with the huge public impact of Argentina's CONADEP report.

This, however, did not prevent future crises and advances in addressing the legacy of authoritarian repression. The unknown fate of the Uruguayan desaparecidos and their disappearance as a result of cooperation between the armed forces of Uruguay and neighboring countries provided a fertile ground for future revelations and reopened public debate. Also, after a period of withdrawal, civil society and part of the political forces returned with new impetus to contest the status quo, reconstruct historical memory and achieve truth and justice.

\section{TESTIMONIAL LITERATURE AND HISTORICAL REVISIONISM}

Despite the ongoing effort to rebuild the civil religion of the Uruguayan people based on the pre-dictatorial model, the image of civility and the principle of citizen sovereignty had been affected as the result of the authoritarian experience, leading many to question whether the professed image of the Nation had not been a fable concocted to seclude the authoritarian character of Uruguay. Important in setting the stage for adjusting human-rights policies to the professed values of the Uruguayan civil religion were the testimonies of political activists who had suffered long-term imprisonment and torture for years (Turiansky, 1988; Rosencof y Fernández Huidobro, 1993; Fried, 2006).

The letters and arts spearheaded criticism on a premature and unreflective closure of the book on the authoritarian past, a policy line promoted by mainstream politicians advancing formulas of national reconciliation. Helping to deepen revisionist perspectives was a novel by Tomás de Mattos (1988), a bestseller that became instantly a focus of reflection not just on the distant past at the center of the book but also on the recent past, 
which those in power were trying to relegate to oblivion without further reflection. Even though the plot unfolds in the distant past, the novel was read as exposing a thread of destructive violence that characterized Uruguay since its birth as a nation (Achúgar, 1989: 61-64; 1994: 99). Also illustrative were Álvaro Ahunchain's theater play “Where were you on June 27, 1973?" referring to the day when president Bordaberry dissolved the Parliament with the support of the armed forces; or the work by historians Vania Markarian, Isabela Cosse and Aldo Marchesi on the educational and cultural policies of the military in the mid-1970s (Cosse y Markarian, 1996; Marchesi, 2001). Years later, the theme of Uruguayan exiles received increasing attention as well (Markarian, 2005; Dutrénit-Bielous, 2006; Dutrénit-Bielous, Allier Montaño and Coraza de los Santos, 2008).

Academic works contributed historical reflection. Editorial Trilce, led by Paul Harari who returned from exile, played a leading role by publishing titles such as Carina Perelli and Juan Rial on myths and political memories (1986); a volume on Uruguayan identity edited by Hugo Achúgar and Gerardo Caetano (1992); and a book on the core themes of the public agenda compiled by Álvaro Rico (1995). These works challenged the complacent view that the dictatorship was a sort of historical accident that affected a population free of authoritarian tendencies. They suggested the need to engage seriously in a review of heart and revisionism that would not leave intact the idealized self-representation of the Uruguayan people.

A gap thus opened in the late 1990s between historical revisionism and the political will of the forces in power unwilling to reopen "old wounds". In 1995 Julio María Sanguinetti, who had been the incumbent head of state during the transition in 1985-90, returned to the presidency for a second term. The president adamantly refused to follow the Chilean example and create a 'dialogue table' between the military and the victims or initiate judicial inquiries into the fate and place of remains of the Uruguayan desaparecidos, the poignant demand by sectors of civil society. Attempts to unlock access to information on the fate and remains of those persons who were assassinated were rejected at that time. There was still fear of encouraging hatred or confrontation and de-stabilize democracy (Caetano, 2002: 18-19). Years later, when the Leftist coalition of the Frente Amplio had taken power and triggered a momentum for policies of accountability, Sanguinetti still supported the amnesty laws and regretted the partiality of the new policies and trends of historical revisionism:

In Uruguay we have immersed in the debate of contemporary history. The Government aims to present in schools and colleges what happened before and during the coup and in the democratic transition. (...) [Yet] the government sees only military crimes, driven by the theory that terrorism is only that which was operated by the state. [My party and others] acknowledge the crimes of the military and were the first to oppose them, but we also recognize the crimes of the guerrilleros that introduced violence and destabilized institutions, creating the context in which the military would act. Now the government opens cracks in the wise amnesty laws and they are putting former President Bordaberry, his Chancellor Juan Carlos Blanco and six officers on trial. In parallel, there is educational 'preaching' in an effort to forget 
that the Left moved to support a military coup in February 1973 [before an actual coup], thinking that the so called "peruanista" sector (inspired by the populist regime of Peruvian General Velasco Alvarado) would prevail, whereas in fact the scale tilted to the other side, and the right-wing sectors of the military repressed the Left (Sanguinetti, 2006).

\section{THE SEARCH FOR PUBLIC RECOGNITION AND JUSTICE}

By the 2000s the narrative of consensus was replaced by a growing recognition of the 'cracks' alluded by Sanguinetti. The debate over the re-signification of the policies of closure soon led to a number of political and legal measures that were converging on a new treatment of the legacy of the violations of human rights and in particular the issue of the desaparecidos and their abducted children. At first incipiently and then assertively a series of developments led to embrace a change of policy and its implementation in the second half of the 2000s.

An early sign was a report by the Inter-American Commission on Human Rights (Mendoza et. al. v. Uruguay, No. 29/92), stating that the Law of Expiry was incompatible with the international standards of human rights. The IACHR also recommended that the Uruguayan government should grant compensations to victims of state repression, take steps to clarify human rights violations, and identify those responsible.

Also contributing to the change of mind was the echo of crises related to past policies of repression in neighboring countries such as Argentina and Chile. The transnational character of repression by task forces of the security apparatuses of South American nations implied that following re-democratization, every revelation in one country had the potential of triggering political unrest in the other countries. Thus, the issue reverberated in Uruguay following the statements by Argentine Navy captain Adolfo Scilingo, who in April 1995 confessed publicly to his participation in flights carrying detainees to sea, where after having been sedated they were dropped with heavy weights from the air so that their remains would never be recovered. In Uruguay, a year later, Navy captain Jorge Néstor Tróccoli followed Scilingo. Then as a student of anthropology, Tróccoli wrote an account acknowledging that despite of not participating himself in acts of torture and murder, he had fought in a war in which the armed forces tortured and murdered their enemies (Tróccoli, 1996; Gil, 1999). A case of cooperation of Uruguayan and Chilean security forces in the kidnapping and assassination in 1993 on Uruguayan territory of a former secret agent of the Chilean DINA who was about to testify in an ongoing trial in Chile, was further troubling. It revealed that transnational repression was not just an occurrence of the past, and that the security forces continued to act with disregard for the rule of law and, if needed, on a transnational scale, perhaps relying on the institutional impunity that accompanied the transition (Roniger and Sznajder, 1999: 109-135).

The trans-generational impact of repression was also evident in the demand for truth and accountability spearheaded by the sons of senator Zelmar Michelini, assassinated in 
Buenos Aires on May 20,1976. In 1996, Rafael Michelini demanded that the Commander in Chief of the Armed Forces, general Curutchet, would follow the example of his Argentine counterpart and recognize the role of the armed forces in repression and human rights violations, a suggestion rejected by Curutchet. Michelini then started organizing annual Marches for Truth, Memory and Never Again, with the support and participation of politicians, trade union activists, religious and social organizations, human rights groups, relatives of the disappeared and victims of repression. The marches stressed the importance of knowing the whereabouts of the victims, while criticizing prevailing impunity.

Still, before the millennium, the road to justice remained closed. Uruguay was a signatory to the Inter-American Convention on Forced Disappearance and had ratified it. And yet, the first attempts of judges to order investigations to determine the existence of mass graves, exhume the bodies and return them to relatives -even without implicating the repressorswas censured by the higher courts. The winds of judicial accountability would change with the inauguration of president Jorge Batlle (2000-2005), as the Executive changed course. Soon trials motivated by the search for truthful information would be joined by criminal trials against perpetrators of human rights violations (Skaar, 2007: 58-59).

On April 2000 president Battle met the families of victims, in what was a first meeting by a Uruguayan president after the return of democracy. The initiative took place a few days after releasing the head of the Joint Chief of Staff general Manuel Fernández from his position and arresting him for 10 days, due to his press statement rejecting any form of clarification on the whereabouts and remains of the disappeared. While high military officers pronounced very hard speeches condemning all forms of historical revisionism, the trade union of Uruguay indicated that the issue could not be avoided and judge Jubette instructed the Executive to initiate inquiries into the whereabouts of a desaparecida (Caetano, 2002: 22-23). President Battle also took an active interest in the notorious cases of extra-legal neonatal adoption of children of desaparecidos, ordering to check the DNA of presumed grandchildren. One case in particular, that of the granddaughter of Argentine Montonero activist and writer Juan Gelman, who was born in prison to Gelman's daughter-in-law, herself forcibly disappeared together with Gelman's son, attained resonance and had institutional implications by the 2000s.

Given the increasing tension and public debate, president Batlle proceeded in August 2000 to establish a Commission for Peace, with the mandate of clarifying the fate of missing persons, portrayed as a 'moral duty of the state' assuming responsibility for a task considered 'indispensable to preserve the historical memory of the country' and 'consolidate national reconciliation and ensure peace forever between all Uruguayans'. The Commission could not subpoena military personnel nor proceed to identify perpetrators, yet it managed to gather information about citizens who had been kidnapped, tortured and killed in secluded detention centers in Uruguay and Argentina between 1971 and 1981. In its final report of August 2003, the Commission confirmed the disappearances and publicly acknowledged that Uruguayans had been murdered after being tortured in military barracks, which then provided an official justification for digging the ground 
in military facilities. The final Commission report also contained recommendations dealing with granting state reparations to the families of the missing, amending the Criminal Code to criminalize torture and enforced disappearances, and establishing a state agency to continue the work on forced disappearances (Informe Final, 2003; Mallinder, 2009: 60-64).

Related to the change of direction by the new President, criminal trials were opened against military personnel implicated in human rights violations. At that time, the proceedings involved cases not explicitly covered by the Law of Expiry's immunity, thus enforcing the hitherto unfulfilled obligation of the Executive to investigate the causes, as contemplated by Article I-4 of the Law. The first criminal trials were concluded in March 2002. One of these involved colonel (r.) José Nino Gavazzo, found guilty of human rights violations; another trial was taking place around the participation of twelve officers in the disappearance of persons as part of Operation Condor, the verdict highlighting the enduring nature of disappearance as a crime against humanity, which the court argued was not covered by the Law of Expiry. The lack of tradition in the application of international law, which characterized the Uruguayan case, as opposed to Argentina and Chile, started breaking down during these proceedings.

Once in office, president Tabaré Vázquez (2005-2009) proceeded to reinterpret Article I-4 of the law, demonstrating a new political will to end impunity. The Law of Expiry referred only to crimes committed by "military and police officers" but did not explicitly address civilians that had collaborated with the repressive policies. In addition, the temporal jurisdiction had no start date, so it was interpreted as excluding acts committed since 1968, under presidents Pacheco Areco and Juan María Bordaberry. In addition, the provision granting immunity was interpreted as excluding senior officers. Finally, the protection did not include disappearances outside the national territory, thus further widening the net on who could be brought to justice even within the limits of the existing law.

The Expiry Law had established that it would be the responsibility of the President to identify cases not covered by immunity and order judicial investigations in those cases. In November 2005 the Vázquez administration sent an interpretive law to Congress that would have enabled judges to proceed investigating cases on their own 'until reaching a point where it was possible to decide whether the case is covered by amnesty or not' (Mallinder, 2009: 52-53). The bill was heavily criticized by the military and the opposition, indicating that its promulgation would threaten internal peace. Faced with strong opposition, the government decided not to push the legislation. Instead, it delegated de facto to the courts reinterpreting the blanket immunity with increasing confidence that such actions would be well received by the Executive. This led to a series of trials of agents implicated in transnational cases. Also highranking officials, as president Bordaberry (1972-1976) and general Álvarez, head of state in 1981-85, were tried and convicted. In the political climate that prevailed after 2005, the military chose to begin providing some information on the remains of the missing. In November 2005, for the first time, remains of a desaparecido were found due to information provided by the Air Force. 


\section{WIDENING COLLECTIVE MEMORY AND NEW LEGAL STRATEGIES}

The institutional developments in the search for truth and the criminalization of past human rights violations were increasingly complemented by initiatives from within civil society. Such initiatives were aimed at recovering popular memory, creating spaces of memory and making contributions in the field of culture and popular practices.

Associations of female political prisoners began to organize after becoming acquainted through their participation in the Marches for Truth. As they met, they shared information and developed insight on the specific nature of female experiences during repression. Civil society also started disputing the use of public spaces, driven by the will to address authoritarianism by working for the conservation of locales that served as detention centers during the dictatorship (Ausserbauer, 2009; Roniger 2012). Likewise, in different neighborhoods and student unions, events have been held to commemorate and honor the memory of victims of repression. Organizers invited people to panel discussions on the struggle against the dictatorship and on impunity (Memoria, 2014). In November 2007 the Mayor of Montevideo Ricardo Ehrlich inaugurated the Museum of Memory of Uruguay, designed to let young generations know the recent history of the country and thus strengthen collective identity (MUME 2014).

These and other practices contributed to rebuild the sense of being part of a society committed to principles and cognizant of past atrocities, and yet attempts to annul the Law of Expiry continued to fail. A public consultation on the possible annulment of the Law, called by the government on October 2009, an initiative that had been promoted by human rights lawyers, legislators and judges since 2006, received only 48 percent of the vote. The administration of José Mujica (2010-14) continued to search for a way to circumvent, if not derogate, the Law of Expiry, as pressure continued to build. The pressure was driven by both international moves and internal forces. On the national scene there persisted the demands of truth and accountability of the relatives of the disappeared and political parties that had been affected severely by the repression, such as the Nuevo Espacio led by the sons of assassinated senator Michelini and the Partido por la Victoria del Pueblo, whose activists were decimated in Argentina in the 1970s. But perhaps the most effective trigger was the pressure put by a demand presented at the Inter-American Commission of Human Rights and Inter-American Court of Justice by Juan Gelman and his granddaughter María Macarena, claiming that the Uruguayan state failed to investigate the case of disappearance of María Macarena's parents due to the constrains of the Law of Expiry, a law that did not meet the standards of the interAmerican normative. Witnessing the imminent condemnation of Brazil on a similar demand, Foreign Minister Luis Almagro convinced president Mujica to forward to Congress an interpretive law that would enable judges by themselves to move forward in investigations and trials. The initiative split political parties, including the ruling Frente Amplio, around the question of whether Congress could pass a law that in fact ignored the popular decision as expressed in 1989 and 2009. Even former victims of repression from Mujica's coalition, such as senator Eleuterio Fernández Huidobro who spent more than a decade in prison, were against the initiative. Finally, on October 2011 
Interpretive Law 18,831 narrowly passed, undoing de facto the blanket impunity of the legal framework of December 1986 (Ley No. 18.831).

\section{CONCLUSIONS: RECONSTRUCTING CIVIL RELIGION THROUGH DISSENT AND CONTESTATION}

On February 2013 the Supreme Court ordered the definitive closure of the still open inquiries in cases of human rights violations, but a minister of the Court explained that it was to judges of lower instances and the prosecution to see how to proceed in specific cases, so that appeals could go on and on. All this triggered continuing disputes and tensions over the legacy of authoritarian repression, unfolding in all domains, from the cultural to the social and from the political to the legal domains. However, these confrontations and debates have differed from those that broke down the democratic system in the late 1960s and early 1970s. They have emerged among the various political forces and social sectors, yet did not agglutinate polarized camps into violence and did not challenge the core values of the reconstructed public domain. On the contrary, they indicated the possibility of maintaining debates without calling into question the agreed upon frameworks of the country. It has been the claim of this article that such development denotes a resurgence of civil religion, a process that in Uruguay was operated through confrontation, albeit with opposing sides meeting in their will to recover the cherished core values of its democracy. These values, involving at least "freedom, democracy, justice and peaceful coexistence", were recovered by a mobilized civil society and the acceptance of the rules of the democratic game by all sectors.

The openings operated in Uruguayans' search for truth and post-transitional justice (or at least, as in the case of Chile, in attaining "as much justice as possible", to follow the words of former Chilean president Patricio Aylwin) have been complemented by the rescue of historical memory and a collective assessment of the past. These achievements have been fundamental building blocks in reconstructing faith in the civil values professed by Uruguayans to depict their society as a democracy that respects individual and collective rights. For an entire generation, Uruguayan society engaged in partial yet intermittent ways of meeting the political, social and legal challenges posed by the past authoritarian repression and the human rights violations that tarnished that perception. As opposing camps dissented and confronted each other, they moved to bring their country closer to the democratic normative of being truthful and accountable in terms of the rule of law and the equality of treatment before the law.

Anthropologist Clifford Geertz used to say that societies tell stories about themselves, projecting models of society and models for society as reflections of themselves and as blueprints for action, respectively. Uruguayans were socialized into conceiving their collective identity in terms of citizenship, civility and universal entitlements to all members of society. It is likely that Uruguayans' observation of the "rules of the game" and cherishing their reconstructed civil premises was possible due to the relative lack of primordial underpinnings in the portrayal of their national identity. In any case, the 
comparative relevance of the Uruguayan case is immense for many societies where contestation often spills over into political polarization, civil wars and human rights violations. ${ }^{5}$

\section{REFERENCES}

Achúgar, Hugo. 1989. "Como el Uruguay no hay. Bernabé Bernabé! y el referendum". Cuadernos de Marcha 41: 61-64. 1994. La biblioteca en ruinas. Montevideo: Trilce.

Achúgar, Hugo y Gerardo Caetano (eds.). 1992. Identidad uruguaya: mito, crisis o afirmación. Trilce.

Achúgar, Mariana. 2006. "Between Remembering and Forgetting: Uruguayan Military Discourse about Human Rights (1974-2004). Discourse and Society 18: 521-547.

2008. What we Remember. The Construction of Memory in Military Discourse. Amsterdam and Philadelphia: John Benjamins.

Alexander, Jeffrey C. (ed.). 1998. Real Civil Societies. London: Sage.

Andacht, Fernando. 1992. Signos reales del Uruguay imaginario. Trilce.

Ausserbauer, Gelsi. 2009. "El barrio Punta de Rieles será un museo vivo de la memoria. Vecinos y ex presas siguen pidiendo la cesión del viejo penal" (June 30). In http://www.larepublica.com.uy/ comunidad/370786-el-barrio-punta-de-rieles-sera-un-museo-vivo-de-la-memoria

Barahona de Brito, Alexandra. 1997. Human Rights and Democratization in Latin America: Uruguay and Chile. Oxford University Press.

Bellah, Robert. 1967. "Civil Religion in America”. Daedalus 96 (1): 1-21.

Benedetti, Mario. 1966. El país de la cola de paja. Montevideo: Asir.

Blancarte, Roberto. 2006. "La laicidad: la construcción de un concepto de validez universal". In Laicidad en América Latina y Europa, edited by Néstor Da Costa. Montevideo: CLAEH, 31-36.

Boidi, María Fernanda. 2014. "Frente Amplio to Govern Uruguay for the Third Time with the Challenge of Sustaining Economic Growth and Combating Insecurity". Americas Barometer and LAPOP Insights, December.

Burt, Jo-Marie. 1989. El pueblo decide. A Brief History of the Referendum Against the Impunity Law in Uruguay. Montevideo: SERPAJ.

Caetano, Gerardo. 2011. La República Batllista. Montevideo: EBO.

2002. "El testamento ciudadano y los riesgos necesarios de la verdad: Cuentas pendientes en el Uruguay contemporáneo". manuscript presented at Universidad de la República.

et al. 1985. De la tradición a la crisis: pasado y presente de nuestro sistema de partidos. Montevideo: CLAEH y Ediciones de la Banda Oriental.

Caetano, Gerardo y Geymonat, Roger. 1997. La secularización uruguaya (1859-1919). Montevideo: Taurus.

Caetano, Gerardo y Rilla, José. 1987. Breve historia de la dictadura. Ediciones de la Banda Oriental.

Camacho, Ana. 1983. "154 hijos de exiliados y presos viajan desde Madrid para pasar la Navidad en Uruguay". El País Archivo (December 24). In: http://elpais.com/diario/1983/12/24/ internacional/441068416_850215.html.

Cosse, Isabela y Vania Markarian. 1996. 1975: Año de la orientalidad: identidad, memoria e historia en una dictadura. Trilce.

Da Costa, Néstor. 2009. "La laicidad uruguaya". Archives de sciences sociales des religions, 54 (146): 137-155. 2011. "El fenómeno de la laicidad como elemento identitario". Civitas (Porto Alegre), 11, 2: 207-220.

De Mattos, Tomás. 1988. Bernabé! Bernabé! Ediciones de la Banda Oriental.

Dutrénit-Bielous, Silvia (eds.). 2006. El Uruguay del exilio. Gente, circunstancias, escenarios. Trilce.

5 Uruguayans have moved to other concerns, among them public insecurity, perceived by half of those surveyed to be the most important contemporary problem of the country (Boidi, 2014). 
Dutrénit-Bielous, Silvia, Allier Montaño, Eugenia y Coraza de los Santos, Enrique. 2008. Tiempos de exilios. Memoria e historia de españoles y uruguayos. CeAlCI-Fundación Carolina e Instituto Mora.

Eisenstadt, Shmuel N. 1995. Power, Trust and Meaning. Chicago: Chicago University Press.

Eisenstadt, Shmuel N. and Luis Roniger. 1984. Patrons, Clients and Friends. Cambridge: Cambridge University Press.

Frazer, Nancy. 1992. "Rethinking the Public Sphere: A Contribution to the Critic of Actually Existing Democracy". In Habermas and the Public Sphere, edited by Craig Calhoun. Massachusetts: MIT Press, $109-142$

Fried, Gabriela. 2006. "Piecing Memory Together after State Terror and Policies of Oblivion in Uruguay: The Female Political Prisoners' Testimonial Project (1997-2004)". Social Identities 12: 543-562.

Gil, Daniel. 1999. El capitán por su boca muere o la piedad de Eros. Trilce.

González, Luis E. 1993. Estructuras políticas y democracia en Uruguay. Fundación de Cultura Universitaria. González Bermejo, Ernesto. 1985. Las manos en el fuego. Ediciones de la Banda Oriental.

Guigou, Lelio Nicolás. 2003. La nación laica: religión civil y mito-praxis en el Uruguay. Montevideo: Ediciones La Gotera (2000 thesis in www.antropologiasocial.org.uy).

. 2010. "Etnicidad y laicismo en el Uruguay". In Un paese che cambia. Saggi antropologici sull'Uruguay tra memoria e attualitá, edited by Carla Maria Rita ed. Roma: CISU, 163-182.

Habermas, Jürgen. 1989. The Structural Transformation of the Public Sphere. Massachusetts: MIT Press.

Halperin Donghi, Tulio. 2002. "Party and State in the Construction of Collective Identities: Uruguay in the Nineteenth Century". In The Collective and the Public in Latin America, edited by Luis Roniger and Tamar Herzog. Brighton: Sussex Academic Press, 158-173.

Hilgers, Tina. 2012. Clientelism in Everyday Latin American Politics. Palgrave Macmillan.

Informe final de la Comisión para la Paz. 10 de abril de 2003. In: http:/ / archivo.prersidencia.gub.uy. Joas, Hans and Klaus Wiedgandt (eds.). 2008. The Cultural Values of Europe. Liverpool University Press.

Kaufman, Edy. 1987. "El rol de los partidos políticos en la redemocratización del Uruguay". In Represión, exilio y democracia: la cultura uruguaya, edited by S. Sosnowski. Ediciones de la Banda Oriental, 25-62.

Kierszenbaum, Leandro. 2012. "Between the Accepted and the Legal: Violence in Honor Disputes in Uruguay (1945-1970)". International Journal of Politics, Culture, and Society 25: 35-48.

"El llamamiento". 1987. Brechs 66 (January 30), 2.

Mallinder, Louise. 2009. Uruguay's Evolving Experience of Amnesty and Civil Society's Response. Belfast: Queen's University.

Marchesi, Aldo. 2001. El Uruguay inventado. La política audiovisual de la dictadura, reflexiones sobre su imaginario. Trilce.

Markarian, Vania. 2005. Left in Transformation: Uruguayan Exiles and the Latin American Human Rights Networks, 1967-1984. New York: Routledge.

Memoria. 2004. "Memoria desde los barrios". In: http:// uruguay.indymedia.org/news/2004/07/26846. php://uruguay.indymedia....

Memoria. 2014. "Memoria que es vida abierta". In: http://www.pim.edu.uy/noticias/memoria-que-es -vida-abierta-homenaje-a-leon-duarte/.

Mendoza et. al. v. Uruguay, Caso 10.029, 10.036, 10.145, 10.305, 10.372, 10.373, 10.374 y 10.375, Informe No. 29/92, IACHR, Ser.L/V/II.83 Doc. 14 at 162 (1993). In: http://www1.umn.edu/humanrts/ cases/Scommissnold.htm\#one.

Museo de la memoria (MUME). 15 January 2014. In: http:/ /mume.montevideo.gub.uy/.

Perelli, Carina y Juan Rial. 1986. De mitos y memorias políticas. Ediciones de la Banda Oriental.

Portillo, Álvaro y Enrique Gallicchio. 1989. Montevideo, Geografía electoral 2. Centro Uruguay Independiente.

Rodríguez, Roger. 1989. "Las brigadas verdes, puerta a puerta: El referéndum llama dos veces". Brecha (February 24), 5.

Rico, Álvaro. 1995. Ed., Uruguay: Cuentas pendientes. Dictadura, memorias y desmemorias. Trilce

Roniger, Luis. 2008. "Uruguay". In Nations and Nationalism. A Global Historical Overview, vol. 1, edited by Guntram H. Herb and David H. Kaplan. Santa Barbara: ABC-CLIO, 393-403.

2012. “La sacralización del consenso nacional y las pugnas por la memoria histórica y la justicia en el Uruguay post-dictatorial". América Latina Hoy 61: 51-78. 
Roniger, Luis and Mario Sznajder. 1999. The Legacy of Human Rights Violations in the Southern Cone. Argentina, Chile and Uruguay. New York: Oxford University Press.

Rosencof, Mauricio y Eleuterio Fernández Huidobro. 1993. Memorias del calabozo. Navarra: Txalaparta-Argitaletxea.

Sanguinetti, JM. 2006. "Julio María Sanguinetti lamenta el desmoronamiento de los modelos de impunidad en Uruguay, Chile, Argentina y España". La Nación (Buenos Aires) (December 22). In: http:/ / www. derechos.org/nizkor/uruguay/doc/sanguinetti.html.

SERPAJ. 2009. "SERPAJ rechaza traslado de presos al ex penal de Punta de Rieles" (April 3). In: http:// www.sociedaduruguaya.org/2009/04/serpaj-rechaza-traslado-de-presos-al-ex-penal-de-punta-de-rieles.html.

Skaar, Elin. 2007. "Legal Developments and Human Rights in Uruguay, 1985-2002". Human Rights Review 8: 58-59.

Seligman, Adam. 1993. The Idea of Civil Society. New York: Free Press.

Sen, Amartya. 2005. The Argumentative Indian. Writings on Indian History, Culture and Identity. New York: Farrar, Straus and Giroux.

Tróccoli, Jorge Néstor. 1996. La ira del Leviatán. Montevideo: Caelum.

Turiansky, Wladimir. 1988. Apuntes contra la desmemoria. Recuerdos de la resistencia. Montevideo: Arca.

Verdesio, Gustavo. 2001. Forgotten Conquests: Rereading New World History from the Margins. Philadelphia: Temple University Press.

Wakeman, Frederick E. Jr. 2009. Telling Chinese History. Berkeley: University of California Press.

Luis Roniger is an Argentinian comparative political sociologist. He is professor of political science and Reynolds Professor of Latin American Studies at Wake Forest University, in the US. He is the author of 18 books and more than 160 academic papers. E-mail: roniger@wfu.edu. 